\title{
Pengembangan Lembar Kegiatan Siswa dalam Pemecahan Masalah Matematika Dengan Pendekatan Metakognitif
}

\author{
Moh. Zayyadi ${ }^{(1),}$ Sri Indriati Hasanah ${ }^{(2)}$, Ahmad Muhaimin ${ }^{(3)}$ \\ ${ }_{1,2,3}$ Prodi Pendidikan Universitas Madura
}

Email: ${ }^{1}$ zayyadi@unira.ac.id, ${ }^{2}$ indriati_math@unira.ac.id

Tersedia Online di

http://www.jurnal.unublitar.ac.id/ index.php/briliant

\begin{tabular}{l}
\hline Sejarah Artikel \\
\hline Diterima pada 13 September \\
2018 \\
Disetuji pada 23 Oktober 2018 \\
Dipublikasikan pada 20 \\
November 2018 Hal. 401-410 \\
\hline Kata Kunci: \\
\hline Pengembangan, Pendekatan \\
Metakognitif, Pemecahan \\
Masalah \\
\hline
\end{tabular}

DOI:

http://dx.doi.org/10.28926/briliant .v3i3.227

\begin{abstract}
Abstrak: Penelitian ini bertujuan untuk mengembangkan Lembar Kegiatan Siswa dalam pemecahan masalah matematika dengan pendekatan metakognitif yang valid, praktis dan efektif. Penelitian ini merupakan penelitian pengembangan yang mengacu pada model 4-D Thiagarajan yang disederhanakan yang menjadi tiga tahap meliputi pendefinisian (define), perancangan (design), pengembangan (develop). Produk yang dihasilkan adalah Lembar Kegiatan Siswa dalam pemecahan masalah dengan Pendekatan Metakognitif, RPP dan Tes Hasil Belajar sehingga tujuan pembelajaran tercapai. Hasil penelitian menunjukkan bahwa Lembar kegiatan Siswa dalam pemecahan masalah pada materi system linear tiga variable dengan pendekatan metakognitif telah dikembangkan memenuhi kriteria valid, praktis dan efektif.
\end{abstract}

\section{PENDAHULUAN}

Dalam rangka mencapai tujuan pembelajaran (standar kompetensi)dalam bahan ajar atau materi pembelajaran (instructional materials) yang terdiri dari kognitif, keterampilan, dan sikap yang harus dipelajari siswa. Bahan ajar yang dimaksud dapat berupa bahan tertulis maupun bahan tidak tertulis. Salah satu contoh bahan ajar secara tertulis adalah Lembar Kerja Siswa (LKS), LKS ini juga dibuat dengan berbagai kurikulum dan pendekatan.LKS yang digunakan haruslah efektif dan efisien serta mampu menjawab kebutuhan siswa dalam memahami suatu materi pembelajaran.Oleh karena itu, LKS peru adanya pegembangan untuk memenuhi kebutuhan siswa. Selain itu, LKS adalah kumpulan berbagai macam soal yang harus dipecahkan dengan tepat sehingga harus ada suatu pemecahan masalah didalamnya.

Nasution (2016) menyatakan bahwa pemecahan masalah adalah proses menemukan beberapa kombinasi pengetahuan atau aturan yang dimiliki sebelumnya untuk digunakan dalam memecahkan masalah yang baru. Zayyadi dan Maulana (2016) mengungkapkan cara berpikir setiap siswa pasti erat kaitannya dengan kemampuan memecahkan masalah matematika. Hal ini dikarenakan dalam pembelajaran dan penyelesaian soal, siswa akan menggunakan pengalaman dan pengetahuan yang dimiliki untuk diterapkan dalam pemecahan masalah sehingga siswa lebih analitik dalam pengambilan keputusan. Pengetahuan 
yang dimiliki oleh siswa sebelumnya dapat digunakan dan perlu adanya proses berpikir untuk memecahkan masalah yang dihadapi oleh siswa. Zayyadi \& Subaidi (2018) menjelaskan memecahkan masalah khususnya masalah aljabar yang didasarkan pada perbedaan kemampuan matematika. Aini \& Hasanah (2016) menyatakan adanya perbedaan hasil belajar matematika antara siswa yang diajar menggunakan strategi pemecahan masalah model polya dengan strategi pembelajaran ekspositori. Oleh karena itu, perlu adanya pendekatan pembelajaran yang mampu mengatasi dalam pemecahan masalah siswa sehingga siswa mampu memberikan sebuah solusi dalam memecahkan masalah yang baru. Salah satu pendekatan yang dapat membantu mensukseskan strategi yang digunakan dalam pemecahan masalah adalah pendekatan keterampilan metakognitif.

Flavell (Lioe et al., 2006) menyatakan bahwa metakognitif adalah pengetahuan dan kesadaran tentang proses kognisi, atau pengetahuan tentang pikiran dan cara kerjanya. Metakognitif merupakan suatu proses menggugah rasa ingin tahu karena kita menggunakan proses kognitif dirikita sendiri. Metakognitif merupakan suatu kemampuan dimana individu berdiri diluar kepalanya dan mencoba untuk memahami cara ia berpikir atau memahami proses kognitif yang dilakukannya dengan melibatkan komponen-komponen perencanaan (functional planning), pengontrolan (self-monitoring), dan evaluasi (self-evaluation).

Keterampilan metakognitif merupakan salah satu pendekatan dalam pembelajaran matematika (Tamalene, 2010; Murni, 2010). Tamalene (2010) menjelaskan pembelajaran dengan pendekatan metakognitif lebih baik dari pembeljaran secara konvensional. Murni (2010) menyatakan bahwa dalam pembelajaran matematika keterampilan metakognitif siswa ikut ambil bagian dalam proses pemecahan masalah yang dilakukan oleh siswa. Dalam hal ini, metakognitif berperan dalam mengatur dan mengevaluasi aktivitas pengetahuan siswa dalam memecahkan masalah sehingga proses pembelajaran matematika khususnya masalah yang dihadapi oleh siswa lebih efektif. Akhirnya, apabila siswa menyadari proses yang digunakan dan apabila mereka belajar untuk mengontrol proses kognitifnya, maka diharapkan kemampuan mereka dalam pemecahan masalah dapat meningkat.Pendekatan keterampilan metakognitif membutuhkan banyak langkah dalam memecahkan masalah sehingga siswa dituntut untuk berpikir tingkat tinggi salah satu contoh materi yang cocok untuk pendekatan keterampilan metakognitif adalah Sistem Persamaan Linear Tiga Variabel (SPLTV). Siswa diharapakan nantinya akan memikirkan dan dapat memberikan pertanyaan terhadap dirinya sendiri tentang pengetahuan, pemahaman, konsep-konsep yang dibutuhkan untuk memecahkan suatu masalah misalnya Sistem Persamaan Linear Tiga Variabel (SPLTV).

Lembar Kerja Siswa yang ada di sekolah-sekolah sejauh ini tidak jauh berbeda dengan buku paket yang berikan pemerintah hanya saja LKS merupakan bahan ajar pendukung dari buku paket tapi isi dari LKS lebih ringkas dari pada buku paket.Sehingga dibutuhkanlah LKS yang berbeda dengan buku paket pemerintah tetapi tetap mengaju pada Kurikulum 13. LKS yang beredar pada siswa hanya menekankan pada kemampuan aspek kognitif siswa tidak bisa menjawab bagaimana solusi cara belajar (proses berpikir) yang cocok digunakan untuk siswa sehingga nantinya siswa dapat mengevaluasi dirinya sendiri dan pada akhirnya kemampuan kognitifnya bisa digunakan secara maksimal, hal ini merupakan salah satu unsur dari metakognitif. Risnawati, dkk (2016) melakukan 
penelitian pengembangan LKS pemecahan masalah kaidah pencacahan dengan pendekatan metakognitif untuk SMA Kelas XI dengan menggunakan pengembangan milik Plomp. Hal ini berbeda dengan penelitian yang akan dilakukan oleh peneliti yang mengembangkan LKS dengan menggunakan model pengembangan sistem instruksional pembelajaran yang dikembangkan oleh Thiagarajan.

Berdasarkan uraian pernyataan di atas, maka penulis mengangkat sebuah judul "Pengembangan Lembar Kegiatan Siswa (LKS) dalam Pemecahan Masalah Matematika dengan Pendekatan Metakognitif".

\section{METODE}

Penelitian ini adalah penelitian pengembangan Lembar Kegiatan Siswa dalam pemecahan masalah matematika dengan pendekatan metakognitif di SMA/MA, Pengembangan Lembar Kegiatan Siswa dalam pemecahan masalah matematika dengan pendekatan metakognitif berorientasi pada produk, karena proses pengembangannya dideskripsikan seteliti mungkin melalui fase-fase pengembangan sampai diperoleh LKS yang berkualitas baik. Produk yang dihasilkan adalah Lembar kegiatan Siswa dalam pemecahan masalah dengan Pendekatan Metakognitif, RPP dan Tes Hasil Belajar sehingga tujuan pembelajaran tercapai.

Berdasarkan ruang lingkup penelitian, subjek uji coba dalam penelitian ini dibatasi pada siswa kelas X MA Nurul Ulum Banyuanyar. Pemilihan subjek uji coba dilakukan dengan memilih kelas $X$ secara acak sebagai tempat pelaksanaan uji coba, siswa yang kelasnya terpilih sebagai tempat pelaksanaan uji coba LKS merupakan subjek uji coba penelitian.

Prosedur pengembangan Lembar Kegiatan Siswa dalam pemecahan masalah matematika dengan pendekatan metakognitif pada model pengembangan system instruksional pembelajaran yang dikembangkan oleh Thiagarajan, $d k k$, (1974) dengan beberapa modifikasi. Berdasarkan hasil modifikasi tersebut, maka tahap-tahap pengembangan LKS , yaitu: tahap pendefinisian, tahap perancangan, dan tahap pengembangan.

Instrumen yang dimaksud pada bagian ini bertujuan untuk mengukur kevalidan, kepraktisan, dan keefektifan LKS dengan pendekatan metakognitif. Karena itu, instrumen yang dipergunakan, yaitu: lembar validasi ahli, angket respons siswa terhadap LKS dengan pendekatan metakognitif dan tes hasil belajar siswa

Teknik analisis data dilakukan untuk mendapatkan produk LKS yang berkulitas yang memenuhi tiga aspek yakni kevalidan, kepraktisan, dan keefektifan. Langkah-langkah dalam menganalisis kriteria kualitas produk yang dikembangkan adalah sebagai berikut:

1. Teknik analisis data lembar validasi materi dan media

Data lembar penilaian terhadap LKS dengan pendekatan metakognitif pada materi sistem persamaan linear tiga variabel dianalisis untuk mengetahui kevalidan produk. Data angket penilaian diolah dengan langkah-langkah sebagai berikut:

a. Peneliti melakukan tabulasi data yang diperoleh dari dosen ahli dan guru matematika. 
b. Mengkonversikan skor rata-rata yang diperoleh menjadi nilaikualitatif sesuai kriteria penilaian Widoyoko (2009:238).

c. Menganalisis kevalidan produk LKS.

2. Teknik analisis kepraktisan

Data angket respon siswa terhadap LKS berbasis metakognitif pada materi sistem persamaan linear tiga variabel digunakan untuk mengetahui kepraktisan terhadap LKS yang dikembangkan. Data yang diperoleh kemudian dianalisis dengan langkah-langkah sebagai berikut:

a.Peneliti melakukan tabulasi data yang diperoleh dari siswa.

b.Mengkonversikan rata-rata skor yang diperoleh menjadi nilai kualitatif sesuai kriteria penilaian.

c. Menganalisis tanggapan/respon siswa terhadap LKS

3. Teknik analisis Keefektifan

Analisis keefektifan dilakukan menggunakan tes hasil belajar dan minat belajar siswa.

a. Hasil tes siswa dinilai berdasarkan pedoman penskoran. Nilai maksimal untuk tes ini adalah 100. Kriteria ketuntasan menggunakan Kriteria Ketuntasan Minimal (KKM) yang digunakan oleh SMA. Analisis dilakukan dengan tahap sebagai berikut:

1) Tabulasi data tes hasil belajar.

2) Mengkonversikan data tes hasil belajar dengan tabel pedoman keefektifan hasil belajar.

3) Menganalisis keefektifan LKS dengan tes soal

Hasil belajar dikatakan efektif jika mencapai persentase jumlah ketuntasan minimal baik. Sedangkan hasil belajar dikatakan sangat baik jika mencapai persentase jumlah ketuntasan $>80$.

b. Hasil minat belajar siswa terhadap LKS menggunakan angket yang diperoleh dari siswa . Penskoran angket minat belajar siswa terhadap LKS, Analisis dilakukan dengan tahap sebagai berikut:

1) Mengkonversikan rata-rata skor yang diperoleh menjadi nilai kualitatif sesuai kriteria penilaian

2) Menganalisis keefektifan LKS dengan minat belajar siswa

\section{HASIL DAN PEMBAHASAN}

\section{Validitas LKS dan Instrumen Penelitian}

a. Lembar Kegiatan Siswa (LKS)

Hasil pengembangan Lembar Kegiatan Siswa (LKS) dalam penelitian ini adalah valid dengan rata-rata total kevalidan sebesar 3,44. Hal iniberarti LKS tersebut telah valid dengan kategori "Sangat Baik". Meskipun kategori yang diperoleh LKS sangat baik, tapi kedua validator memberikan saran agar LKS yang dikembangkan dilakukan sedikit revisi terutama pada penulisan.Selain LKS yang menjadi perhatian utama terdapat beberapa perangkat pendukung yang divalidasi oleh validator yaitu: Rencana Pelaksanaan Pembelajaran (RPP), dan soal tes. Kedua perangkat tersebut digunakan dalam proses kegiatan belajar mengajar sehingga perangkat pembelajaran yang digunakan tidak melenceng dari materi. Beberapa revisi yang terdapat pada LKS seperti pada tabel 1 berikut ini : 
Tabel 1. Revisi LKS

\begin{tabular}{|c|c|c|}
\hline $\begin{array}{c}\text { Yang } \\
\text { direvisi }\end{array}$ & Sebelum direvisi & Sesudah direvisi \\
\hline Bab 1 & 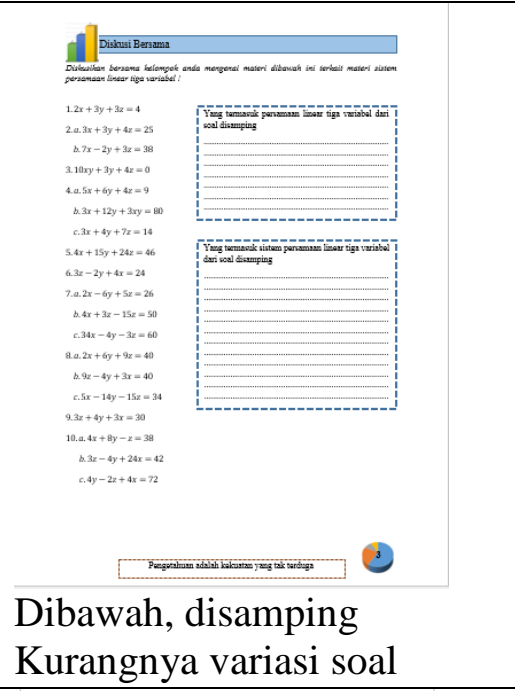 & 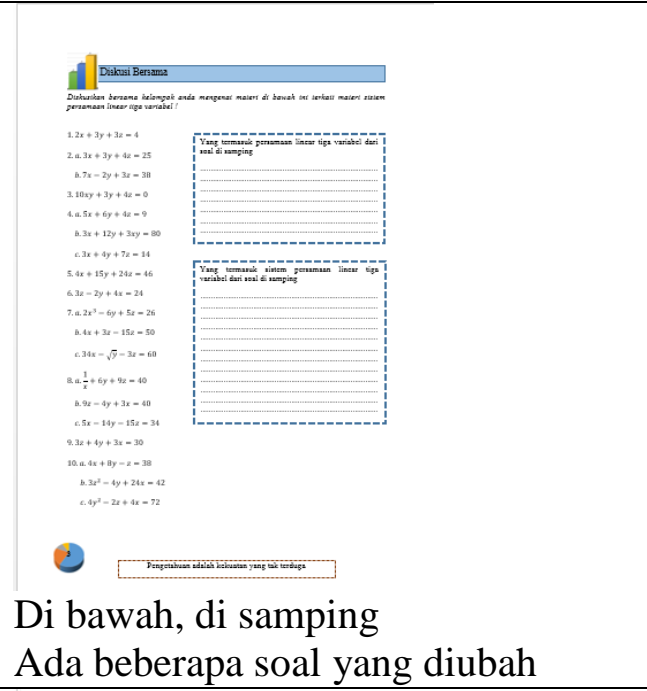 \\
\hline Bab 2 & 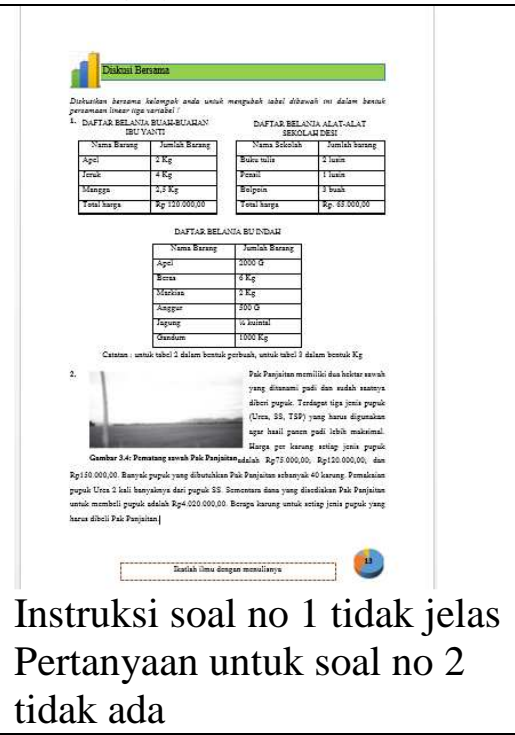 & $\begin{array}{l}\text { Pas } \\
\text { Penulisan no } 1 \text { dipindah ke atas } \\
\text { Pertanyaan no } 2 \text { ditulis dengan jelas }\end{array}$ \\
\hline $\begin{array}{l}\text { Latihan } \\
\text { Mandiri }\end{array}$ & 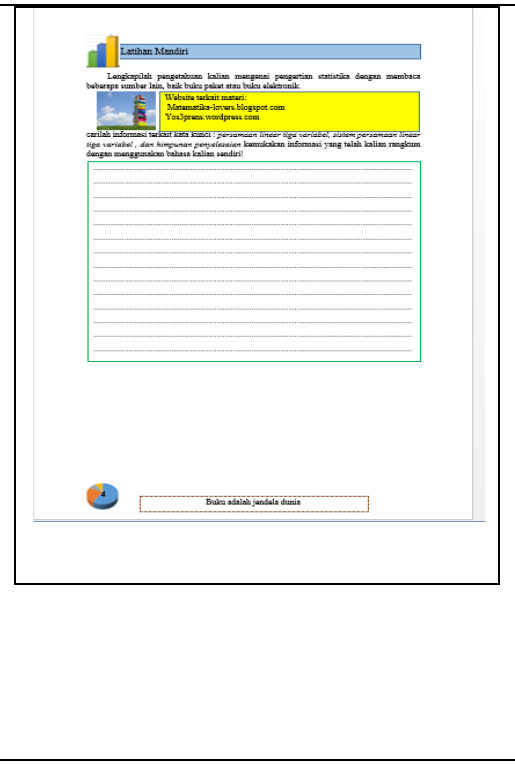 & $\begin{array}{l}\text { Tugas yang diberikan berupa } \\
\text { melengkapi pengetahuan dengan } \\
\text { mencari informasi terkait kata kunci } \\
\text { yang berkaitan dengan materi, hal ini } \\
\text { sesuai dengan indikator pada }\end{array}$ \\
\hline
\end{tabular}




\begin{tabular}{|c|c|c|}
\hline & & $\begin{array}{l}\text { pengetahuan metakognisi yaitu } \\
\text { menggambarkan konsep suatu unit dak } \\
\text { saling keterkaitannya. }\end{array}$ \\
\hline $\begin{array}{l}\text { Jurnal } \\
\text { Belajar }\end{array}$ & 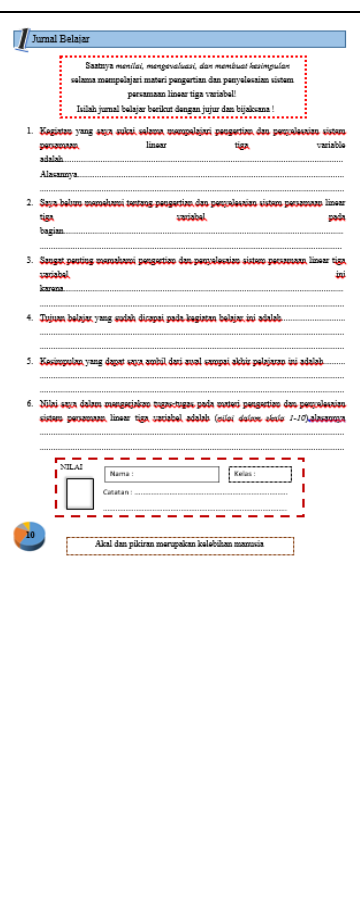 & $\begin{array}{l}\text { Jul } \\
\text { Jurnal belajar ditempatkan pada setiap } \\
\text { akhir bab. Tujuannyaagar sebagai } \\
\text { refleksi siswa setelah pembelajaran } \\
\text { dilakukan. Dengan adanya jurnal } \\
\text { belajar, diharapkan siswa sadar akan } \\
\text { kemampuan yang dimiliki setelah } \\
\text { melakukan pembelajaran. }\end{array}$ \\
\hline
\end{tabular}

b. Rencana Pelaksanaan Pembelajaran (RPP)

Hasil pengemabangan pada Rencana Pelaksanaan Pembelajaran (RPP) memiliki nilai rata-rata total kevalidan sebesar 3,76. Hal ini berarti RPP tersebut telah valid dengan kategori "Sangat Baik". Berdasarkan hasil validasi dari kedua validator maka dapat disimpulkan RPP tersebut dapat digunakan tanpa revisi namun ada beberapa catatan dari kedua validator. Beberapa revisi yang terdapat pada RPP seperti pada tabel 2 berikut ini :

Tabel 2. Revisi RPP

\begin{tabular}{|c|c|c|}
\hline $\begin{array}{c}\text { Yang } \\
\text { direvisi }\end{array}$ & Sebelum direvisi & Sesudah direvisi \\
\hline \multirow[t]{2}{*}{ RP 01} & $\begin{array}{l}\text { C. Indikator Pencapaian Hasil } \\
\text { Belajar }\end{array}$ & \\
\hline & $\begin{array}{l}\text { 2. menulis sikap bekerjasama } \\
\text { dalam mengejakan tugas } \\
\text { kelompok } \\
\text { Tidak ada PR untuk siswa }\end{array}$ & $\begin{array}{l}\text { 2. menunjukkan sikap } \\
\text { bekerjasama dalam mengejakan } \\
\text { tugas kelompok } \\
\text { Ada PR untuk siswa }\end{array}$ \\
\hline RP 01 & $\begin{array}{l}\text { Guru tidak membentuk siswa } \\
\text { menjadi beberapa kelompok } \\
\text { setiap kelompok terdiri dari } 3 \\
\text { orang }\end{array}$ & $\begin{array}{l}\text { Guru membentuk siswa menjadi } \\
\text { beberapa kelompok setiap } \\
\text { kelompok terdiri dari } 3 \text { orang }\end{array}$ \\
\hline RP 01 & Guru tidak memberikan PR & Guru memberikan PR \\
\hline $\mathrm{RP} 02$ & $\begin{array}{l}\text { a. Pendahuluan } \\
\text { (tidak ada) ...bersama siswa } \\
\text { membahas PR yang dianggap ... }\end{array}$ & $\begin{array}{l}(\text { ada }) \ldots \text { bersama siswa } \\
\text { membahas PR yang dianggap }\end{array}$ \\
\hline
\end{tabular}

406 BRILIANT: Jurnal Riset dan Konseptual

Volume 3 Nomor 4, November 2018 
c. Tes

Hasil Tes pada penelitian ini memiliki rata-rata total kevalidan sebesar 3,9. Hal ini menunjukkan soal tes tersebut telah valid dengan kategori “ Sangat Baik". Berdasarkan hasil validasi dari kedua validator maka dapat disimpulkan Tes tersebut dapat digunakan namun ada catatan dari kedua validator. Beberapa revisi yang terdapat pada Soal Tes seperti pada tabel 3 berikut ini :

Tabel 3. Revisi Tes Hasil Belajar

\begin{tabular}{lll}
\hline $\begin{array}{c}\text { Yang } \\
\text { direvisi }\end{array}$ & \multicolumn{1}{c}{ Sebelum direvisi } & \multicolumn{1}{c}{ Sesudah direvisi } \\
\hline No. 3 & ......sehingga uang yang & ......sehingga uang yang \\
& dikeluarkan Brian sebesar Rp. & dikeluarkan Brian sebesar Rp. \\
& 1.000,00.Jika harga sebuah buku & 1.000,00.Jika harga sebuah buku \\
& tulis adalah Rp 2.000,00, & $\begin{array}{l}\text { tulis adalah Rp 2.000,00 maka } \\
\text { tentukan harga sebuah pena? }\end{array}$ \\
\end{tabular}

1. Hasil Analisis Kepraktisan Lembar Kegiatan Siswa (LKS)

Hasil ujicoba yang dilakukan di MA Nurul Ulum menunjukkan bahwa LKS dalam pemecahan masalah dengan pendekatan metakognitif bersifat praktis. Praktis yaitu LKS tepat digunakan dalam pembelajaran matematika yang dibuat dengan pendekatan metakognitif. Kepraktisan LKS dalam pemecahan masalah dengan pendekatan metakognitif dengan materi sistem persamaan linear tiga variable dapat memudahkan siswa dalam memahami materi, lebih menarik digunakan, siswa lebih aktif dalam pembelajaran, LKS ini dapat mengetahui kemampuan siswa itu sendiri. Data tersebut menunjukkan bahwa hasil penilaian kepraktisan Lembar Kegiatan Siswa (LKS) diperoleh dari angket yang sudah diisi sebesar 3,25 yang termasuk dalam kategori "baik".

2. Hasil Analisis Keefektifan Penggunaan LKS

Berdasarkan analisis hasil belajar siswa dengan menggunakan soal tes yang telah dikemukakan sebelumnya, menunjukkan bahwa 15 siswa tuntas secara individual, artinya siswa telah mencapai kompetensi yang telah ditetapkan yaitu memahami masalah yang berkaitan dengan sistem persamaan linear tiga variabel. Selain itu siswa juga memenuhi kriteria ketuntasan klasikal, karena persentase jumlah siswa yang tuntas sebesar $88,2 \%$, sehingga dapat dikatakan bahwa secara keseluruhan siswa telah mencapai kompetensi yang telah ditentukan. Dengan demikian, ditinjau dari hasil belajar siswa, penggunaan LKS dengan pendekatan metakognitif memenuhi kriteria efektif.

Terdapat 2 orang siswa yang tidak tuntas dalam mencapai kompetensi memahami masalah yang berkaitan dengan sistem persamaan linear tiga variabel, dengan nilai hasil soal tes di bawah 60. Menurut peneliti, siswa yang tidak tuntas tersebut dari awal kurang memperhatikan selama kegiatan pembelajaran dan cenderung tidak serius. Hal inilah yang mungkin menjadi salah satu faktor penyebab tidak tuntasnya siswa dalam mencapaikompetensi yang telah ditetapkan. Selain menggunakan indikator soal tes peneliti juga menggunakan angket minat belajar siswa untuk mengukur keefektifan LKS. 


\section{Uji Coba Lembar Kegiatan Siswa}

\section{a. Aktivitas Siswa}

LKS dalam pemecahan masalah matematika dengan pendekatan metakognitif yang telah dibuat dan diujicobakan telah memenuhi kriteria efektif, dimana aspek pertama mengukur keaktifan bertanya, aspek kedua mengukur keterampilan dalam mengerjakan soal/keterampilan dalam menyelesaikan masalah dengan berbagai cara, aspek ketiga mengukur ketepatan mengerjakan soal, aspek keempat mengukur keterlibatan dalam kelompok. Pada pertemuan pertama total skor yang diperoleh dari observer 1 adalah 221 dengan rata-rata 3,25 , total skor yang diperoleh dari observer 2 adalah 222 dengan rata-rata 3,26, sehingga diperoleh rata-rata kedua skor 3,255. Pada pertemuan kedua total skor yang diperoleh dari observer 1 adalah 225 dengan rata-rata 3,31, total skor yang diperoleh dari observer 2 adalah 226 dengan rata-rata 3,32, sehingga diperoleh rata-rata kedua skor 3,315. seluruh aktivitas siswa pada pertemuan pertama dan kedua memenuhi kriteria efektif dengan keterangan "baik".

b. Aktivitas Guru

Berdasarkan analisis data yang telah dilakukan sebelumnya aktivitas guru menunjukkan bahwa guru sudah menunjukkan kemampuan terbaiknya dalam proses pembelajaran. Hal ini di dasarkan pada setiap indikator untuk aktivitas guru telah memenuhi kriteria efektif, dimana indikator pertama mengukur kemampuan guru pada tahap awal yang meliputi 4 indikator penilaian, indikator kedua mengukur kemampuan guru pada tahap inti yang meliputi 8 indikator penilaian, indikator ketiga mengukur kemampuan guru pada tahap akhir yang meliputi 3 indikator penilaian. Pada pertemuan pertama total skor yang diperoleh dari observer 1 adalah 52 dengan rata-rata 3,5, total skor yang diperoleh dari observer 2 adalah 55 dengan rata-rata 3,7, sehingga diperoleh rata-rata kedua skor 3,6 . Pada pertemuan kedua total skor yang diperoleh dari observer 1 adalah 54 dengan rata-rata 3,6, total skor yang diperoleh dari observer 2 adalah 57 dengan rata-rata 3,8, sehingga diperoleh rata-rata kedua skor 3,7. seluruh aktivitas guru pada pertemuan pertama dan kedua memenuhi kriteria efektif dengan keterangan "sangat baik".

\section{c. Minat Siswa}

Hasil minat belajar siswa terhadap LKS menggunakan angket yang diperoleh dari siswa menunjukkan minat belajar siswa "Sangat Baik" saat menggunakan LKS. Hasil tersebut diambil dari rata-rata minat belajar siswa yaitu sebesar 3,41.Dari ketuntasan belajar dengan angket minat belajar siswa, maka dapatdisimpulkan bahawa LKS tersebut bersifat efektif dengan kategori "Sangat Baik".

\section{KESIMPULAN}

Setelah dilakukan validasi, dan uji coba maka peneliti dalam penelitian ini memberikan kesimpulan sebagai berikut:

a) Perangkat pembelajaran matematika SMA/MA yang dikembangkan terdiri dari: Lembar Kegiatan Siswa (LKS) dalam pemecahan masalah matematika dengan pendekatan metakognitif pada materi system linear tiga vaiabel dengan rata-rata total kevalidan sebesar 3,44. Hal ini menunjukkan LKS tersebut telah 
valid dengan kategori "Sangat Baik", akan tetapi ada sedikit revisi terutama dari segi penulisan.

b) Selain LKS dalam pemecahan masalah matematika dengan pendekatan metakognitif pada materi system linear tiga vaiabel yang divalidasi ada juga beberapa perangkat pembelajaran lain yaitu: Rencana Pelaksanaan Pembelajaran (RPP) dan soal tes. Keduanya digunakan sebagai pendukung dalam proses pembelajaran. Rencana Pelaksanaan Pembelajaran (RPP) pada penelitian ini memiliki rata-rata total kevalidan sebesar 3,76 yang berarti RPP tersebut telah valid dengan kategori "Sangat Baik".Soal tes pada penelitian ini memiliki rata-rata total kevalidan sebesar 3,9 yang berarti soal tes tersebut telah valid dengan kategori "Sangat Baik".

c) Aktivitas siswa telah memenuhi kriteria efektif, dengan keterangan aktivitas siswa baik.

d) Berdasarkan analisis respon siswa terhadap kepraktisan Lembar Kegiatan Siswa (LKS) dalam pemecahan masalah matematika dengan pendekatan metakognitif pada materi system linear tiga vaiabel diperoleh dari angket yang sudah diisi sebesar 3,25 yang termasuk dalam kategori "baik".

e) Hasil belajar siswa kelas X MA Nurul Ulum Banyuanyar diperoleh melalui dua indikator diantaranya sebagai berikut:

1) Berdasarkan analisis hasil belajar siswa dengan menggunakan soal tes menunjukkan bahwa 15 siswa tuntas secara individual dengan persentase jumlah siswa yang tuntas sebesar $88,2 \%$, sehingga dapat dikatakan bahwa secara keseluruhan siswa telah mencapai kompetensi yang telah ditentukan.

2) Hasil minat belajar siswa terhadap LKS dalam pemecahan masalah matematika dengan pendekatan metakognitif pada materi system linear tiga vaiabel menggunakan angket yang diperoleh dari siswa menunjukkan minat belajar siswa "Sangat Baik" saat menggunakan LKS. Hasil tersebut diambil dari rata-rata minat belajar siswa yaitu sebesar 3,41 .

3) Dari ketuntasan belajar dengan angket minat belajar siswa, maka dapat disimpulkan bahawa LKS dalam pemecahan masalah matematika dengan pendekatan metakognitif pada materi system linear tiga vaiabel tersebut bersifat efektif dengan kategori "Sangat Baik".

\section{SARAN}

Penelitian ini hanya sampai tahap pengembangan, untuk mengetahui seberapa besar efektifnya Lembar Kegiatan Siswa (LKS) dan untuk mengetahui apakah ada perbedaan hasil belajar siswa yang mengikuti pembelajaran menggunakan Lembar Kegiatan Siswa (LKS) dengan pendekatan metakognitif dengan Lembar Kegiatan Siswa (LKS) yang lainnya, maka peneliti memberikan penelitian ini dapat dilanjutkan ke penelitian eksperimen pada penelitian berikutnya. 


\section{DAFTAR RUJUKAN}

Aini, S,D dan Hasanah,S, I. Hasil Belajar Matematika Antara Siswa yang Diajar Menggunakan Strategi Pemecahan Masalah Model Polya dengan Strategi Pembelajaran Ekspositori. Jurnal Sigma. 1(2), 47-51.

Lioe, L.T; Fai, H.K; Hedberg, J.G. 2006. Students'Metacognitive Problem Solving Strategies in Solving Open-ended Problems in Pairs. [Online]. Tersesdia:http://conference.nie.edu.sg/paper/new converted/aboo 287.pdf. [10 Mei 2010].

Murni, A. 2010. Pembelajaran Matematika Dengan Pendekatan Metakognitif Berbasis Masalah Kontekstual. Seminar Nasional Matematika dan Pendidikan Matematika: Yogyakarta.

Nasution, R dan Halimah, S, 2016. Upaya Meningkatkan Kemampuan Pemecahan Masalah dan Kemampuan Berpikir Kreatif Matematika Dengan Menggunakan Pendekatan Open Ended Pada Siswa di Kelas VIII SMP Muhammadiyah 02 Medan Tahun Ajaran 2015/2016. AXIOM. V(2). 280288

Plomp, T, 1997. Educational and Training System Design. Enschede, The Netherlands:Univercity of Twente.

Risnawati, dkk. 2016. Pengembangan LKS Pemecahan Masalah Kaidah Pencacahan Dengan Pendekatan Metakognitif Untuk SMA Kelas XI. Jurnal penelitian dan pembelajaran Matematika. 9(1). 138-144.

Tamalene, H. 2010. Pembelajaran Matematika Dengan Model Core Melalui Pendekatan Keterampilan Metakognitif Untuk Meningkatkan Kemampuan Penalaran Matematis Siswa Sekolah Menengah Pertama : Studi Eksperimen Pada Salah Satu SMP Negeri di Kota Ambon. S2 thesis, Universitas Pendidikan Indonesia.

Thiagarajan, S., Semmel, D. S \& Semmel, M. I. 1974. Instructional Development for Training Teachers of Expectional Children. Minneapolis, Minnesota: Leadership Training Institute/Special Education, University of Minnesota.

Widoyoko. E.P. 2009. Evaluasi Program Pembelajaran.Yogyakarta; Pustaka Belajar.

Zayyadi, M., \& Maulana, W.H. 2016. Profil Berpikir Siswa Sekolah Menengah Kejuruan Dalam Memecahkan Masalah Matematika Ditinjau Dari Gender. Prosiding Seminar Nasional Pendidikan Matematika 2016 Prodi Pendidikan Matematika Universitas Madura

Zayyadi, M., \& Subaidi, A. 2018. Berpikir Kritis Mahasiswa Dalam Memecahkan Masalah Aljabar. Paedagoria FKIP UMMat, 8(2), 10-15 